\title{
Peran Sosial Majlis Taklim (Perintisan Majlis Taklim Az-Zahra, Gondoriyo, Ngaliyan Sebagai Lembaga Amil Zakat)
}

\author{
Nasihun Amin \\ Universitas Islam Negeri Walisongo Semarang
}

\begin{abstract}
This paper attempts to unravel efforts made a majlis taklim to transform into an amil zakat institutions. The role of zakat institutions will be more pronounced benefits than just being a majlis taklim. It is to embody the image of Indonesian Islam as a representation of Islam, especially in relation to Social-economic welfare, should be formed either amil zakat institutions. Which of course is not merely the responsibility of the large organizations, but also social institutions that are rooted down to the lowest level so that the impact is even really be felt by the community. One of them is the Majlis Taklim az-Zahra who had attempted to pioneer its existence not merely as a study group that only focuses on spirituality problems alone, but also perform a variety of social activities. Especially after held assistance through various activities both workshops, studies, comparative studies and so forth. Proven has started there is a small movement that is gathering a bit of money every week when there recitation.
\end{abstract}

Abstrak: Tulisan ini mencoba mengungkap upaya yang dilakukan sebuah majlis taklim untuk bertransformasi menjadi lembaga amil zakat. Peran lembaga amil zakat akan lebih terasa manfaatnya dari pada hanya menjadi sebuah majlis taklim. Hal tersebut untuk mewujudkan citra Islam Indonesia sebagai representasi Islam, khusunya dalam kaitannya dengan kesejahteraan sosil-ekonomi, perlu dibentuk lembaga amil zakat yang baik. Yang tentu bukan hanya semata menjadi tanggungjawab organisasi-organisasi besar, melainkan juga lembaga-lembaga kemasyarakatan yang sifatnya mengakar sampai ke tingkat yang paling rendah sekalipun sehingga dampaknya memang betul-betul bisa dirasakan oleh masyarakat. Salah satunya adalah Majlis Taklim az-Zahra yang telah berusaha merintis keberadaannya bukan hanya sebatas sebagai sebuah kelompok pengajian 
yang berkutat dalam masalah ritualitas semata, tetapi juga melakukan berbagai aktivitas social. Lebih-lebih setelah diadakan pendampingan melalui berbagai kegiatan baik workshop, kajian-kajian, studi banding dan sebagainya. Terbukti telah mulai ada gerakan kecil yaitu mengumpulkan sedikit dana setiap seminggu sekali ketika ada pengajian.

Kata Kunci: peran, majlis taklim, lembaga amil zakat

\section{PENDAHULUAN}

Salah satu lembaga keagamaan yang sekarang ini banyak menjamur di masyarakat adalah majlis taklim. Keberadaannya menjadi cukup penting karena melalui lembaga ini proses pemahaman keagamaan dan keberagamaan masyarakat menjadi meningkat. Ada banyak sekali corak majlis taklim yang berkembang di masyarakat. Dari yang berada di lapisan masyarakat bawah, di desa-desa sampai di masyarakat lapisan atas yang mengadakan kegiatannya di berbagai hotel berbintang. Fenomena urban sufism adalah salah satu contoh nyata adanya sebentuk majlis taklim. Melihat fenomena ini, bisa dikatakan bahwa keberadaan majlis taklim menjadi strategis.

Kendati mempunyai posisi yang strategis, namun peran yang dimainkanmajlis taklim masih sangat terbatas pada aktivitas keagamaan dalam pengertian yang terbatas. Mestinya majlis taklim bukan saja, menjadi arena berkumpul orang-orang yang hendak melaksanakan ritual keagamaan, semacam pembacaan yasin dan tahlil, kajian-kajian keagamaan dan sejenisnya, melainkan lebih luas dari itu adalah keterlibatan dalam berbagai kpersoalan sosial secara umum sebagai bentuk implementasi keberagamaan yang lebih luas.

Oleh karena itu dalam konteks sekarang ini, untuk bisa memaminkan peran yang luas, majlis taklim memerlukan adanya sebuah sentuhan yang didasarkan pada realitas sosial dan perkembangan aspek-aspek manajerial yang efisien efektif. Dengan dasar seperti ini maka majlis taklim bisa memainkan peran di sektor sosial yang lebih baik. Salah satu peran yang bisa dimainkannya adalah menjadkannya sebagai Lembaga Amil Zakat (LAZ). Melalui lembaga ini diharapkan mampu menjadi daya tarik bagi masyarakat untuk memercayakan penyaluran kekayaan mereka.

\section{Zakat: Alternatif Solusi Problem Sosial-Ekonomi}

Dalam konteks agama-agama, banyak pihak menilai bahwa Islam merupakan agama dengan sumber ajaran dan sejarah yang paling kaya serta 
paling mungkin untuk terus melakukan berbagai perubahan. Baik hal itu berkaitan dengan perubahan individual maupun social. Ajaran-ajaran tentang kesejahteraan dan keadilan social merupakan bukti nyata betapa Islam sangat menaruh perhatian terhadapnya.

Sebagai agama yang datang untuk kehidupan manusia, Islam tidak saja harus ma'qul/sensible, bisa dicerna logika penalaran, tapi juga harus ma'mul/applicable, bisa dicerna oleh lagika kesejarahan. Logika penalaran mewujud dalam ungkapan-ungkapan teoritis, sedangkan logika kesejarahan mewujud dalam hal-hal yang bersifat empiric. Berbeda dengan logika teoritik yang bersifat abstrak dan subyektif, logika empiris bersifat konkret dan obyektif. Sesuatu bisa disebut applicable jika hal iti bisa dijabarkan ke dalam kerangka kerja sisitem yang bisa dikontrol dan diukur. Ini berarti yang sensible belum tentu applicable, tetapi yang applicable tentulah sensible. ${ }^{1}$ Secara khusus, pokok-pokok pikiran sebagaimana dijelaskan ini, terejawantahkan ke dalam salah satu ajaran yang terlembagakan yang disebutnya sendiri dengan zakat.

Secara bahasa, zakat dapat diartikan sebagai thaharah (kesucian), shadaqah (empati), nabaat (tumbuhan), numuwwah atau ziyadah (kesuburan, pertumbuhan, perkembangan atau pertambahan), dan thayyibaat (kebaikan). Sedangkan secara istilah adalah hartab tertentu yang wajib dikeluarkan oleh orang Islam dan diberikan kepada golongan tertentu yang berhak menerimanya sesuai dengan ketenetuan syaraiah.

Dipandang dri segi pengertiannya, zakat berarti kebersihan dan pertumbuhan, sesuai dengan yang tersebut dalam al-Quran ( QS al-Taubah: 103). Zakat dimaksudkan untuk membersihkan harta benda orang lain yang dengan sengaja atau tidak telah masuk ke dalam harta kita. Akibatnya banyak orang yang merasa dirugikan. Hanya saja mereka tidak berani menuntut Karen tidak cukup bukti. Untuk itu, untuk memberishkan harta dari kemungkinan seperti itu, maka zakat dibayarkan. Zakat juga berarti pertumbuhan, karena dengan memberikan hak kepada fakir miskin dan lain-lain yang terdapat dalam harta benda kita, maka terjadilah suatu sirkulasi uang dalam masyarakat yang mengakibatkan bertambah dan berkembangnya fungsi uang itu. ${ }^{2}$

Dalam Islam, zakat menempati posisi yang sangat strategis. Ia menjadi salah satu pilar dalam Islam (arkan al-Islam) yang berhubungan langsung dengan

1 Masdar Farid Mas'udi, “Zakat: Konsep Harta yang Bersih” dalam Budhy MunawarRachman, Kontekstualisasi Doktrin Islam dalam Sejarah (Jakarta: Paramadina, 1994), hlm. 424.

2 A. Rahman Zainuddin, "Zakat: Implikasi pada Pemerataan" dalam Budhy MunawarRachman, Kontekstualisasi, hlm. 434. 
kehidupan riil di masyarakat. Dengan kata lain, zakat merupakan dasar prinsipil untuk menegakkan struktur sosial Islam. Zakat bukanlah derma atau sedekah biasa, ia adalah sedekah wajib. Bahkan dalam sejarah Islam, mereka yang tidak mengeluarkan zakat akan mendapatkan sanksi yang berat. Umar ibn Khattab, ketika menjabat khalifah, pernah memerintahkan untuk membakar rumah orang Islam yang menolak perintah zakat. Begitu seriusnya perintah zakat itu diperhatikan sehingga ia menjadi syarat keislaman dan keimanan seseorang. Dari sini bisa dipahami bahwa Islam benar-benar memberikan perhatian serius untuk mewujudkan tataanan social yang berkeseimbangan.

Dengan semakin kompleksnya masalah kehidupan dan luasnya wilayah Islam, maka pengelolaan zakat yang professional, yang efektif dan efisien menjadi sebuah keniscayaan. Dengan pengelolaan yang demikian, diharapkan kesulitan dan penderitaan fakir miskin dapat berkurang. Di samping itu dengan pengelolaan zakat yang profesional, berbagai permasalahan yang terjadi dalam masyarakat yang ada hubungannya dengan mustahiq juga dapat dipecahkan.

Dari penjelasan di atas bisa dipahami bahwa zakat adalah salah satu bentuk distribusi kekayaan di kalangan umat Islam sendiri. Pemberian sejumlah harta dari golongan umat yang kaya kepada golongan umat yang miskin, agar tidak terjadi jurang pemisah antara golongan kaya dan golongan miskin, serta untuk menghindari penumpukan kekayaan pada golongan kaya saja. Artinya, melalui zakat diharapkan, kelompok masyarakat tertentu yang dulunya miskin bisa berubah menjadi lebih baik.

Ada dua macam jenis zakat dalam Islam yaitu zakat fitrah dan zakat mal (harta). Zakat fitrah adalah zakat yang diwajibkan pada akhir puasa Ramadhan. Hukum zakat fitrah wajib atas setiap orang Islam, kecil atau dewasa, laki-laki atau perempuan, budak atau merdeka. Sedangkan zakat mal adalah bagian dari harta kekayaan seseorang atau badan hukum yang wajib diberikan kepada orangorang tertentu setelah mencapai jumlah minimal tertentu (dalam istilah teknisnya disebut nishab) dan setelah dimiliki selama jangka waktu tertentu pula (dalamm istilah teknisnya disubut haul. Berbeda dengan zakat fitrah, kewajiban zakat mal hanya ditujukan kepada orang-oorang tertentu yang kepemilikan hartanya telah mencapai nishab dan haul.

Penghitungan zakat maal disesuaikan dengan nishab, kadar dan waktunya ditetapkan berdasarkan hukum agama. Pengumpulan dikelola oleh amil zakat dengan cara menerima/mengambil dari murakki atas dasar pemberitahuan muzakki. Badan amil zakat dapat bekerjasama dengan bank dalam pengumpulan zakat harta muzakki yang berada di bank atas permintaan murak.ki. Tata cara 
pengumpulan dana zakat dilakukan dengan cara pemungutan atau pemotongan yang sebelumnya telah disepakati oleh instansi.

Melalui zakat, masyarakat mempunyai sumber dana potensial yang dapat dimanfaatkan sebagai upaya untuk mewujudkan kesejahteraan rakyat. Hanya saja, apa yang menjadi idealitas ajaran zakat sangat sulit direalisasikan jika pengelolaan zakat dibiarkan tidak termanage secara baik. Artinya secara pribadipribadi, masyarakat yang wajib mengeluarkan zakat menyalurkan sendiri dengan prinsip "yang penting telah mengeluarkan zakat". Zakat hanya akan menjadi fungsionjal jika dikelola secara baik mengingat ada banyak tahapan dan pekejaan yang harus dilaksanakan.

Keberhasilan pengelolaan zakat sesungguhnya tidak hanya tergantung pada banyaknya dana yang terkumpul, keluasan distribusi, melainkan juga sangat tergantung pada dampak dari pengelolaan zakat tersebut dalam masyarakat. Zakat baru dapat dikatakan berhasil dalam pengkelolaannya, apabila zakat tersebut benar $\neg$-benar dapat mewujudkan kesejahteraan dan keadilan sosial dalam masyarakat; mampu mengurang jumlah mustahiq karena berubah keadaan darin mustahiq menjadi bukan mustahiq. Keadaan yang demikian sangat tergantung dari manajemen yang diterapkan oleh amil zakat dan kemauan politis dari pemerintah.

Untuk mencapai tujuan ditetapkannya zakat, hal pertama yang harus dipahamkan secara luas, baik anggota masyarakat yang wajib mengeluarkan zakat maupunh mereka yang dipercaya mengelola zakat adalah mengenai filosofi zakat. Sayangnya tentang filosofi zakat ini tak banyak dibahas. Karena itu, kewajiban zakat menjadi kurang begitu diperhatikan oleh orang Islam, atau setidaknya banyak yang berusaha mengelak agar dirinya terhindar dari zakat. Hitung-hitungan jumlah harta yang terkena zakat menjadi sering dipermainkan, baik secara nishab maupun haul. Pada prakteknya, jiwa sosialisme tidak terbentuk sama sekali oleh perintah zakat.

Berkaitan dengan filosofi zakat ini, Quraish Shihab ${ }^{3}$ menegaskan bahwa zakat adalah ibadah yang berkaitan dengan harta benda. Seseorang yang telah memenuhi syarat-syaratnya dituntut untuk menunaikannya, bukan semata-mata atas dasar kemurahan hatinya, tapi kalau terpaksa dengan tekanan penguasa. Ada tiga hal, menurutnya,yang menjadi landasan filosofis kewajiban zakat. Pertama adalah istikblaf (penugasan sebagai khalifah di bumi). Allah Swt adalah pemilik seluruh alam raya dan segala isinya, tentu saja termasuk harta benda di dalamnya.

3 Baca: M. Quraish Shihab, Membumikan al-Quran, Fungsi dan Peran Wabyu dalam Kehidupan Masyarakat (Bandung: Mizan, 1996), hlm. 323-325. 
Seseorang yang beruntung memperolehnya, pada hakikatnya hanya menerima titipan sebagai amanat untuk disalurkan dan dibelanjakan sesuai dengan kehendak pemiliknya sehingga mereka wajib memenuhi ketetapan-ketetapan yang digariskan oleh pemilik, baik dalam pengembangan harta maupun dalam penggunaannya.

Zakat merupakan salah satu ketetapan Tuhan menyangkut harta, bahkan shadaqah dan infaq pun demikian. Sebab, Allah swt menjadikan harta benda sebagai sarana kehidupan untuk umat manusia seluruhnya. Karena itu, harta benda harus diarahkan guna kepentingan bersama. Allah melarang manusia memberikan harga benda kepada siapapun yang diduga kuat akan menyianyiakannya. Sebab, tindakan itu akan merugikan semua pihak. Sejak awal, Tuhan telah menetapkan bahwa harga hendaknya digunakan untuk kepentingan bersama.

Kedua, Solidaritas sosial. Manusia adalah makhluk sosial sehingga keberadaannya tidak akan bermakna tanpa adanya pihak tang lain. Kebersamaan antara beberapa individu dalam suatu wilayah membentuk masyarakat. Walaupun mereka berbeda sifatnya satu dengan yang lain, namun individuindividu tersebut tidak bisa dipisahkan darinya. Ada banyak pengetahuan yang diperoleh melalui masyarakatnya seperti bahasa, adat istiadat, sopan santun dan lain-lain. Demikian juga dalam kaitannya dengan kepemilikan harta benda yang sifatnya materia, diperolehnya hanya berkat bantuan pihak-pihak lain baik secara langsung atau tidak, disadari atau tidak.

Ketiga, Persaudaraan. Jika ditelusur, manusia sesungguhnya berasal dari satu keturunan, antara seseorang dengan lainnya terdapat pertalian darah, dekat atau jauh. Artinya semua manusia adalah bersaudara. Pertalian darah tersebut pada gilrannya menjadi menguat karena adanya persamaan-persamaan lain, seperti agama, kebangsaan, lokasi domisili dan sebagainya.

Sebagaimana layaknya dalam hubungan persauadaraan, dituntut adanya sebuah pola yang bukan sekadar hubungan take and give (mengambil dan menerima), atau pertukaran manfaat, akan tetapi lebih jauh dari itu semua, yakni memberi tanpa mengharap imbalan atau membantu tanpa diminta. Apalagi, jika mereka hidup bersama dalam satu lokasi.

Sebagaimana diuraikan pada bagian depan, bahwa ajaran Islam untuk kehidupan manusia di dunia seharusnya máqul/sensible sekaligus juga ma'mul/applicable, maka filosofi zakat yang amat dalam ini tidak akan menjadi kenyataan jika tidak disertai adanya langkah-langkah konkretnya yang bisa dirancang, dikontrol dan diukur hasilnya.. Oleh karena itu, pelaksanaan zakat melibatkan sejumlah kegiatan yang berkaitan dengan pengelolaan harta benda 
sejak pengumpulan, pendistribusian, pengawasan, pengadministrasian, dan pertanggung jawaban harta zakat. Oleh sebab itu pelaksanaan zakat tersebut lagilagi memerlukan suatu manajemen yang baik sehingga dapat meningkatkan peranan dan fungsi zakat dalam mewujudkan kesejahteraan dan keadilan sosial.

Untuk menciptakan manajemen zakat yang baik, maka diperlukan persyaratan-persyaratan tertentu, seperti; 1) Kesadaran masyarakat akan makna, tujuan serta hikmah zakat; 2) Amil zakat benar-benar orang-orang yang terpercaya, karena masalah zakat adalah masalah yang sensitif. Oleh karena itu dibutuhkan adanya kejujuran dan keikhlasan dari amil zakat untuk menumbuhkan adanya kepercayaan masyarakat kepada amil zakat; dan 3) Perencanaan dan pengawasan atas pelaksanaan pemungutan zakat yang baik dan profesional.

Untuk itu, sebagai negara dengan penduduk Islam terbanyak, maka Indonesia mempunyai kepentingan untuk mengatur pengelolaannya dengan serius. Bisa dibayangkan berapa besar dana yang bisa dikelola melalui zakat dari Indonesia. Sehubungan dengan itu, pada tanggal 23 September 1999 Presiden RI, B.J. Habibie mengesahkan Undang-undang Nomor 38 Tahun 1999 tentang Pengelolaan Zakat. Untuk melaksanakan Undang-undang Nomor 38 Tahun 1999 tentang Zakat tersebut, Menteri Agama RI menetapkan Keputusan Menteri Agama RI Nomor 581 Tahun 1999 yang mulai berlaku padam tanggal 13 Oktober 1999. Namun, karena Undang-undang tersebut dinilai telah tidak bisa mengikuti perkembangann zaman, maka kemudian Undang-undang tersebut diganti dengan Undang-undang baru yaitu Undang-undang No. 23 Tahun 2011

Pengelolaan zakat secara professional ini diperlukan agar zakat bisa fungsional dan tepat sasaran sesuai dengan tujuan yang telah ditetapkan dalam pasal 3 Undang-undang No 23 Tahun 2011 tentang Pengelolaan Zakat. Adapun tujuan pengelolaan zakat adalah. pertama, meningkatkan efektivitas dan efisiensi pelayanan dalam pengelolaan zakat; kedua, meningkatkan manfaat zakat untuk mewujudkan kesejahteraan masyarakat dan penanggulangan kemiskinan.

Pengelolaan zakat hanya bisa dilaksanakan dengan baik, jika ditangani oleh sebuah lembaga yang baik. Maka, secara tegas Undang-undang ini juga membicarakan secara khusus mengena organisasi pengelola zakat. Dalam Bab II pasal 5 sampai dengan 20 UU No. 23 tahun 2011 secara khusus membicarakan dua institusi pengelola zakat yaitu Badan Amil Zakat (BAZ) yang keberadaannya ada di tingkat nasional sampai daerah secara struktural-hierarchis dan Lembaga Amil Zakat (LAZ) yang tidak struktural. Keduanya berbeda secara prinsipil dari sisi siapa yang membentuknya. BAZ adalah lembega pengelola zakat yang 
dibentuk oleh pemerintah sedangkan LAZ adalah lembaga pengelola zakat yang dibentuk oleh masyarakat. Kedua lembaga ini yang secara resmi disebut sebagai amil zakat. Dengan kata lain amil zakat merupakan orang-orang yang terlibat atau ikut aktif dalam kegiatan pelaksanaan zakat.

Ada cukup banyak aktivitas yang harus dilakukan oleh lembaga amil zakat. Di antara aktivitas tersebut adalah mendata para wajib zakat (muzakki),mpenentukan bentuk wajib zakat dan besarnya zakat yang harus dikeluarkan, mengumpulkan zakat dari muzakki. Setelah hal ini dilakukan kemudian lembaga amil zakat mendoakan orang yang membayar zakat; menyimpan, menjaga dan memelihara harta zakat sebelum dibagikan kepada mustahiq. Disamping berbagai kegiatan berkaitan dengan muzakki, juga cukup banyak kegiatan yang harus dilakukan berkaitan dengan mustahiq yaitu mencatat nama-nama mustahiq, menentukan prioritas mustahiq; menentukan besarnya bagian yang akan diberikan kepada para mustahiq; membagikan harta zakat kepada para mustabiq; Sebagai sebuah lembaga yang diharapkan bisa melaksanakan pengelolaan secara profesional, mereka juga berkewajiban mencatat, mengadministrasikan semua kegiatan pengelolaan tersebut, dan mempertanggungjawabkannya sesuai dengan ketentuan yang berlaku serta mendayagunakan dan mengembangkan harta zakat

Demikian kompleksnya tugas yang hatus dilaksanakan oleh amil zakat, maka lembaga ini tidak boleh dikelola secara sambil lalu dan sembarangan. Lembaga ini harus mempunyai sandaran hukum yang jelas sehingga ketika ada pihak-pihka yang ingin mempersoalkannya, lembaga ini tetap bisa berdiri kokoh.

Melalui Undang-undang No 23 tahun 2011 berarti keberadaan lembaga amil zakat mempunyai kekuatan hukum. Adapun beberapa keuntungan yang dapat diperoleh dari pengelolaan zakat yang dilakukan oleh pengelola zakat yang mempunyai kekuatan hukum formal, yaitu; a) Untuk menjamin kepastian dan disiplin dalam membayar zakat; b) Untuk menjaga perasaan para mustabiq zakat apabila berhadapan langsung untuk menerima zakat dari para muzakki; c) Untuk mencapai efisien dan efektifitas serta sasaran yang tepat dalam penggunaan harta zakat menurut skala prioritas; dan d) Untuk memperlihatkan syi'ar Islami.

Disamping itu secara manajemen juga harus bertul-betul terlatih segingga menjadi sebuah lembaga yang efisien dan efektif melakukan perannya. Sekalipun lembaga amil zakat ini mempunnyai tugas yang tidak ringan, ia bisa dibentuk oleh pemerintah yang disebut badan amil zakat ataupun oleh masyarakat yang disebut lembaga amil zakat. Yang disebut kedua ini bisa berdiri sendiri atau merupakan bagian dari organisasi sosial keagamaan maupun pemerintah daerah. Untuk mewujudkan fungsi zakat yang strategis, maka manajemen suatu lembaga 
amil zakat harus memenuhi tiga kualifikasi utama yaitu amanah, profesional dan transparan. Amanah merupakan syarat mutlak yang harus dimiliki oleh setiap amil zakat. Terlebih dana yang dikelola oleh amil zakat tersebut adalah hak milik dari mustahiq. Karena muzakki setelah memberikan dananya kepada amil zakat tidak ada keinginan sedikitpun untuk mengambil dananya lagi. Sehingga kondisi tersebut menuntut dimilikinya sifat amanah dari para amil zakat.

Selaian amanah, juga harus profesional. Dengan profesionalitas yang tinggi membuat dana-dana yang dikelola akan menjadi efektif dan efisien. Setiap amil harus berperilaku konsisten dengan reputasi profesi yang baik dan menjauhi tindakan yang dapat mendiskreditkan profesi. Ia dilaksanakn berdasarkan prosedur operasi standar yang telah ditetapkan sehingga betul-betul terukur Kewajiban untuk menjauhi tingkah laku yang dapat mendiskreditkan profesi harus dipenuhi oleh amil sebagai perwujudan tanggung jawabnya kepada muzakki, mustabiq, mitra, sesama amil dan masyarakat pada umumnya.

Transparan juga menjadi kualifikasi yang tidak bisa diabaikan., Dengan transparannya pengelolaan zakat, maka akan menciptakan suatu sistem kontrol yang baik. Karena hal ini tidak hanya melibatkan pihak intern organisasi saja tetapi juga melibatkan pihak ekstern seperti para muzakki maupun masyarakat luas. Sehingga dengan transparansi inilah rasa curiga dan ketidakpercayaan masyarakat akan dapat diminimalisasi.

Dari hasil pengumpulan zakat tersebut kemudian didayagunakan untuk orangorang yang berhak menerima zakat (mustahiq), sebagaimana firman Allah SWT dalam surat At-Taubah ayat 60, yaitu; 1) Fakir, yaitu orang-orang yang tidak mempunyai harta atau penghasilan yang layak untuk memenuhi kebutuhan pokoknya baik untuk dirinya sendiri maupun untuk keluarganya. 2) Miskin, yaitu orang yang mempunyai penghasilan tetap tetapi tidak cukup untuk memenuhi kebutuhannya sehari-hari. 3) Amil, yaitu orang-orang yang bekerja dalam pengumpulan zakat dan pendistribusiannya. Mereka berhak memperoleh bagian sesuai dengan standar yang didasarkan pada kompetensi pekerjaannya. Namun diharapkan bagiannya sama dengan bagian mustahiq yang lainnya. Lebih baik amil zakat adalah pihak yang sudah digaji oleh sumber dana bukan zakat. 4) Muallaf, yaitu orang yang belum lama masuk Islam, belum kuat Iman dan Islamnya. Orang ini berhak menerima zakat dengan tujuan agar Iman dan Islamnya menjadi kuat. 5) Riqab (budak), yaitu budak yang telah dijanjikan oleh tuannya akan merdeka bila telah melunasi harga dirinya yang telah ditetapkan. Oleh karena itu mereka dibantu dengan harta zakat untuk membebaskan mereka dari belenggu perbudakan. 6) Gharim, yaitu orang-orang yang mempunyai hutang dan tidak mempunyai bagian lebih dari hutangnya, baik 
atas hutang untuk kemaslahatan dirinya sendiri maupun untuk kemaslahatan masyarakat. 7) Fisabilillah, yaitu orang-orang yang berjuang dijalan Allah dengan tujuan untuk mendapatkan keridhaan dari Allah baik berupa ilmu maupun amal perbuatan. Dan 8) Ibnu Sabil, yaitu orang yang sedang dalam perjalanan yang bukan maksiat mengalami kesengsaraan dalam perjalanan karena kehabisan biaya.

Dari berbagai uraian di atas, secara umum bisa dikatakann bahwa untuk mendapatkan amil zakat yang efektif dan efisien, maka ada dua hal yang harus dilakukan. Pertama, pengelola yang siddiq dan amanah. Pengelola yang siddiq berarti adalah pengelola yang jujur. Seluruh orang yang terlibat dalam pengelolaan tanpa kecuali harus jujur dalam melaksanakan tugasnya. Karena itu pengelola yang siddiq harus jujur perkataan dan perilakunya. Kemudian pengelola yang amanah berarti dapat dipercaya dan penuh rasa tanggung jawab melaksanakan dengan sungguh-sungguh tugas yang diserahkan kepadanya.

Kedua, sistem pengelolaan yang tabligh dan fathanah. Tabligh adalagh adalah pengelolaan yang berbasis pada transparansi atau keterbukaan. Pengelolaan yang transparan diwujudkan dalam hubungan baik antara pengelola dan anggota, antar pengelola, dan antara pengelola dan pemerintah. Hal ini akan mewujud antara perbuatan dan perkataannya sama, catatan keuangannya sesuai kenyataan, pemasukan dan pengeluaran selalu dicatat sesuai dengan ketentuan, pelayanan yang cepat dan tepat. Sedangkan pengelolaan yang fathanah adalah pengelolaan professional yang berbasis pada Standar Operating Procedure dan Standar Operasional Manajemen yang jelas yang dipahami dan dilaksanakan oleh seluruh amil zakat. ${ }^{4}$

\section{Kegiatan Pendampingan}

Salah satu majlis taklim yang berusaha untuk mengembangkan peranperan sosialnya adalah majlis taklim az-Zahra, Gondoriyo, Ngaliyan, Semarang. Latarbelakang terbentuknya majlis taklim ini adalah adanya rasa prihatin banyaknya ibu-ibu, hampir semuanya adalah ibu-ibu muda, yang kurang mempunyai pengetahuan agama. Sementara ada kenyataan, bahwa anak-anak mereka, yang pada waktu itu masih tergolong balita, akan tumbuh menjadi

4 Prinsip pengelolaan ini yang dijadikan landasan dan diterapkan oleh Koperasi BMT UGT Sidogiri dan Koperasi BMT Maslahah yang semula kecil kemudian terus berkembang dan dinobatkan sebagai Koperasi Jasa Keuangan Syariah terbesar pertama dan kedua tingkat nasional. Keduanya berbais di Pesntren Sidogiri. Selengkapnya baca: Mokh Syaiful Bakhri, Sukeses Koperasi Syariah di Sidogiri The Best Islamic Micro Finance (Cipta Pustaka Utama, 2015). 
remaja. Sebagai ibu, yang mempunyai tanggungjawab untuk mengarahkan dan membimbing anak-anak, muncul kesadaran pentingnya agama sebagai pegangan. Di samping kesadaran seperti itu, mereka juga merasa perlu adanya sebuah media silaturrahim, untuk menjaga kerukunan dan keakraban di antara mereka, karena masing-masing sibuk dengan kegiatan.

Berdasarkan tahun kelahirannya, sesungguhnya usia majlis taklim ini bisa dikatakan masih remaja dan masih berada dalam fase perkembangan dan pertumbuhan. Dalam rentang waktu kurang lebih empat belas tahun, majlis taklim ini telah berganti-ganti kepemimpinan. Namun demikian, kendati telah berganti-ganti kepemimpinan, nuansa majlis taklim ini tetap sama yaitu membaca Yasin dan Tahlil yang sesekali diselingi dengan ceramah agama.

Pada awal berdirinya, majlis taklim ini tidak mempunyai nama dan kegiatannya pun sangat terbatas pada Yasin dan Tahlil. Tetapi seiring dengan perjalanan waktu, majlis taklim ini mengalami berbagai perkembangan. Perkembangan pertama adalah identitas lembaga yang dulunya tak bernama, pada tahun 2012 kemudian disepakati bernama Majlis Taklim Az-Zahra .

Filosofi penggunaan nama Az-Zahra adalah tabarrukan kepada putri Nabi Muhammad, Fathimah, yang digelari az-Zahra. Melalui penamaan ini, anggota majlis taklim diharapkan mempunyai kerpibadian seindah kepribadian putri Nabi Muhammad. Az-Zahra juga berarti bunga yang indah. Dari sini diharapkan para anggota majlis taklim bisa menajdi bunga yang indah yang menghiasi kehidupan dan semerbak wangi harumnya.

Secara institusional, Majlis Taklim Az-Zahra akhirnya menetapkan sebuah visi yaitu Majlis Peningkatan Kesalehan Pribadi dan Sosial. Penetapan visi ini tentu bukan tanpa alasan. Realitas bahwa, pengetahuan keislaman yang belum memadai mengakibatkan keberagamaan masyarakat masih timpang. Masyarakat memahami bahwa agama adalah ritual yang sifatnya individual. Sementara aktivitas social belum menjadi bagian yang terperhatikan dalam kehidupan adalah feomena-fenomena yang mendorong rumusan visi tersebut.

Untuk dapat mewujudkan visi itu, misi-misi yang ditetapkan sebagai langkah pencapaian visi meliputi; a) Menyelenggarakan kajian keagamaan secara komprehensif. b) Menjadikan majlis taklim sebagai media penguatan sosial yang djiwai oleh nilai-nilai agama. c) Meningkatkan kualitas sumber daya manusia di wilayah majlis taklim berada. Dan d) Perkembangan lain adalah pada aspek kegiatannya yang tidak hanya berupa membaca Yasin dan Tahlil, akan tetapi mendapatkan sentuhanh-sentuhan baru yang lebih kreatif. Sehingga sebagai sebuah lembaga yang didirikan untuk memberikan media mengekspresikan keberagamaan masyaraka sehingga bisa menjadi wahana kesalehan pribadi dan 
sosialt, aktivitas Az-Zahra cukup variatif. bisa dikelompokkan menjadi dua yaitu aktivitas mandiri dan aktivitas kerjasama.

Aktivitas mandiri adalah aktivitas yang dilaksanakan tanpa adanya keterlibatan pihak lain. Aktivitas ini murni dilaksanakan sendiri oleh majlis taklim az-Zahra. Aktivitas yang dapat dikelompokkan dalam kegiatan ini adalah pengajian rutin yang dilaksanakan pada malam jumat. Sedangkan aktivitas kerjasama adalah aktivitas yang dilaksanakan secara bersama-sama dengan lembaga lain. Dalam hal ini terutama adalah Masjid Jabal Nur yang ada di kawasan Perumahan Griya Lestari. Adapun program kerja yang dicanangkan oleh majlis taklimAz-Zahra bisa dilihat di tabel 1.

Kendati telah mengalami pertkembangan yang cukup signifikan, tetapi dari berbagai kegiatan yang dilaksanakan oleh majlis taklim tersebut masih sebatas kegiatan keagamaan yang sangat terbatas, belum mempunyai kegiatan yang berdampak sosial secara nyata. Berkaitan dengan pelaksanaan peran sosial majlis taklim, khususnya perintisannya sebagai lembaga amil zakat, beberapa program kegiatan yang dijalankan antara lain; pertama, Sosialisasi Gerakan Masyarakat Sadar Zakat (Gemar Zakat). Kegiatan ini adalah sebuah gerakan yang ditujukan kepada masyarakat di wilayah keberadaan Majlis Taklim az-Zahra secara keseluruhan. Kegiatan ini lebih banyak berupa pembinaan dan pemahaman tentang arti pentingnya zakat, infaq dan sadaqah bagi keberadaan msyarakat. melalui berbagai kegiatan keagamaan seperti forum pengajian ibuibu, khutbah jumat dan sebagainya.

Di samping itu, majlis taklim bersama dengan takmir masjid juga mengadakan sebuah kegiatan yang berlabel PROGRAM KItA (Kajian Intensif tetang Agama). Program ini dirancang untuk memberikan pemahaman yang semakin intensif dan komprehensif mengenai Islam, sehingga tidak hanya berada pada kulit luar melainkan masuk ke dalam filosof ajaran.

Dengan format seperti ini, diharapkan masyarakat mengetahui mengapa sesuatu itu diperintahkan atau sebaliknya, dilarang sehimgga menjadi semakin mantap dan yakin. Zakat, misalnya, tidak hanya dipahami sebagai sebuah keharusan karena diperintah, akan tetapi apa reasoning dibalik perintah diharuskannya berzakat juga dipahami secara baik bahwa ada misi keadilan social ekonomi supaya tidak terjadiketimpangan.

\section{Tabel 1}

Program kerja Majlis Taklim Az-Zahra

\begin{tabular}{|l|c|c|}
\hline NO & PROGRAM & TARGET \\
\hline 1. & Konsolidasi pengurus & Terciptanya kepengurusan yang solid \\
\hline
\end{tabular}




\begin{tabular}{|l|l|l|}
\hline 2. & Penataan administrasi & $\begin{array}{l}\text { Terwujudnya system administrasi dan } \\
\text { manajemen yang tertib }\end{array}$ \\
\hline 3. & Kajian Tafsir & $\begin{array}{l}\text { Meningkatkan pengetahuan dan } \\
\text { pemahaman mengenai al-Quran yang } \\
\text { lebih baik }\end{array}$ \\
\hline 4. & Kajian Fiqh & $\begin{array}{l}\text { Meningkatkan pelaksanaan ibadah sesuai } \\
\text { dengan ketentuan yang berlaku }\end{array}$ \\
\hline 5. & Hafalan surat pendek & $\begin{array}{l}\text { Mempunyai hafalan alQuran untuk } \\
\text { aktivitas keseharian }\end{array}$ \\
\hline 6. & $\begin{array}{l}\text { Membuat halaqah } \\
\text { takhtim al-Quran bi } \\
\text { al-nadhar }\end{array}$ & $\begin{array}{l}\text { Membentuk forum untuk mengoreksi } \\
\text { bacaan sesuai dengan kaidah yang berlaku }\end{array}$ \\
\hline 7. & PHBI & $\begin{array}{l}\text { Meningkatkan kesadaran dan kecintaan } \\
\text { terhadap hari bersejarah dalam Islam }\end{array}$ \\
\hline 8. & Dana Sosial & $\begin{array}{l}\text { Tersedianya dana yang memadai untuk } \\
\text { merealisasikan aberbagai aktivitas social. }\end{array}$ \\
\hline 9. & Halal Bihalal & Menumbuhkan semangat silaturrahami \\
\hline 10. & Ziarah ke para aulia & $\begin{array}{l}\text { Mendapatkan inspirasi perjuangan para } \\
\text { wali }\end{array}$ \\
\hline
\end{tabular}

Kedua, Workshop. Kegiatan lain yang diadakan dalam adalah Workshop: Peningkatan Peran Masjid/Majlis Taklim sebagai Lembaga Amil Zakat. Pada mulanya workshop diorientasikan hanya untuk para pengurus Majlis Taklim AzZahra. Namun berdasarkan pertimbangan praktis agar semua elemen masyarakat atau jamaah masjid memahami makna dan keberadaan majlis taklim serta essensi ajaran Islam, maka workshop diperluas untuk seluruh komponen yang ada. Workshop: Peningkatan Peran Masjid/Majlis Taklim sebagai Lembaga Amil Zakat ini dilaksanakan pada tanggal 19 Juni 2016. Workshop ini sengaja di rancang dengan melibatkan semua komponen, baik pengelola maupun jamaah, orang tua maupun remaja, sebagai peserta. Harapannya agar semua tergugah kesadarannya dan menjadikan masjid dan majlis taklim sebagai media untuk ikut memberikan kontribusi dalam penyelesaian berbagai problem social ekonomi masyarakat.

Usaha mewujudkan masjid dan majlis taklim yang telah dimiliki menjadi lembaga amil zakat bukanlah pekerjaan ringan, melainkan hal itu merupakan pekerjaan yang cukup berat. Namun harus ada kesadaran yang tumbuh bahwa keberadaan keduanya sedemikian penting bagi perkembangan kehidupan masyarakat, terutama untuk mereka yang kurang beruntung secara ekonomi. 
Ketiga, Studi Banding. Kegiatan ini dilakasanakan dengan adanya satu keyakinan bahwa salah satu cara efisien untuk meningkatkan kinerja sebuah lembaga adalah melalui belajar dari pengalaman pihak lain. Apa langkah-langkah praktis yang dilakukan oleh lembaga lain tersebut, bisa ditru sambil melakukan beberapa inovasi lainnya. Hanya saja, karena secara teknis agak sulit menemukan majlis taklim yang mempunyai pengelolaan zakat, infaq dan sadaqah secara baik, maka akhirnya kegiatan studi banding dilaksanakan dengan mengambil obyek masjid.

Masjid dimaksud adalah Masjid Jogokariyan, Yogyakarta yang terletak di RW Kampung Jogokaryan, Yogyakarta. Masjid ini dipimpin oleh $\mathrm{H}$. Muhammad Fanni Rahman, SIP. Adapun yang membawahi pengelolaan kekayaan masjid adalah HM Rizqi Rahim, ST, M.Eng, sebagai bendahara sekaligus ketua baitul mal. Masjid ini tergolong masjid dengan struktur kepengeurusan yang gemuk karena melibatkan sebanyak 156 personil dalam kepengurusannya. Salah satu biro penting yang berhubungan dengan pengelolaan zakat adalah biro Zakat, Infaq, Sadaqah dan Wakaf (Ziswaf) yang dikomandani oleh Ismail Toha Putra, SH .

Pilihan terhadap Masjid Jogokariyan sebagai obyek studi banding adalah dengan pertimbangan bahwa masjid tersebut bukanlah sebuah masjid besar, melainkan masjid yang sederhana yang terletak di pusat masyarakat abangan, akan tetapi akhirnya mampu menggerakkan masyarakat sekitarnya untuk penuh kesadaran mengembangkan potensi masyarakat sehingga bisa membalik keadaan. Dari pengalaman konkret pengelolaan Masjid Jogokaryan ini, diharapkan majlis taklim az-Zahra bersinergi dengan pengelola Masjid Jabal Nur mempunyai keyakinan bahwa upayanya untuk semakin meningkatkan perannya akan bisa dilaksanakan dengan baik. Berbeda dengan jika studi banding dilakukan di sebuah masjid yang besar yang mempunyai sumber dana telah disediakan oleh sebuah yayasan besar, tentu akan terasa berat untuk dapat merealisasikannya.

Pada mulanya masjid ini adalah masjid kampong yang kecil, tetapi seiring perjalanan waktu akhirnya menjadi masjid sebagai tempat jujugan dari berbagai masjid di Indonesia yang ingin mengembangkan manajemen masjid.

Pola pikir utama yang dikembangkan oleh Masjid Jogokariyan adalah memberikan pelayanan sebaik-baiknya kepada masyarakat. Untuk melaksanakannya langkah pertama yang dilakukan adalah melakukan pemetaan terhadap kondisi obyektif masyarakat yang menjadi wilayah cakupan kerja masjid yang terdiri dari empat RW. Dengan adanya peta kondisi obyektif ini, pengurus 
Masjid Jogokaryan berusaha memberikan seusatu sesuai dengan apa yang dibutuhkan oleh masyarakat. Bukan apa yang diinginkan oleh masjid.

Pemetaan ini menjadi penting dilakukan dalam rangka untuk mengetahui potensi yang dimiliki oleh kampung Jogokaryan. Dari sini kemudian dilakukan klasifikasi warga berdasar usia, ekonomi, pengetahuan agama, hobi, profesi dan sebagainya, Berdasarkan inilah pengelola Masjid Jogokaryan akhirnya, merumuskan program-program yang ditawarkan.

Dari sisi kegiatan yang berkaitan dengan akitivitas zakat, infaq, sadaqah dan wakaf, kegiatan pemetaan ini menjadi penting. Dari mereka yang secara ekonomi masuk dalam kategori muzakki kemudian secara door to door yang dilakukan oleh para remaja. Pada awalnya memang dilakukan jemput bola, akan tetapi setelah berkembang dengan baik, karena adanya kepercayaan yang terbangun, pada akhirnya mereka yang ingin memberikan ziswaf, langsung datang ke takmir masjid baik dalam bentuk material (seperti beras) maupun uang.

Ada tiga program menarik yang dikembangkan oleh masjid ini yaitu Program Jamaah Mandiri, Program Masjid Mandiri dan Program Masjid Mberkahi. Program pertama adalah program dimana setiap jamaah secara mandiri ikut menanngung dirinya sendiri dalam opersionalisasi masjid seperti listrik, air, kebersihan dan sebaginya. Seperti diketahui bahwa masjid setiap hari mempunyai beban operasional baik dari sector listrik, air, muballigh dan sebagainya. Beban ini dihitung sehingga setiap jamaah diketahui mempunyai beban Rp 1.500,-/minggu. Maka, jika jamaah, dalam satu minggu memberikan infaqnya sebesar itu, berarti ia telah membiayai dirinya sendiri. Jika kurang, berarti dia masih disubsidi oleh jamaah lain, dan jika lebih berarti dia telah mensubsidi jamaah lain.

Program kedua adalah program dimana masjid tidak bergantung kepada pihak lain untuk menopang dirinya. Dalam program ini kemudian dibuat beberapa unit usaha seperti penginapan, penyewaan aula dan sebagainya. Dengan adanya unit usaha ini, maka berbagai aktivitas masjid bisa di danai sendiri oleh masjid tanpa mengandalkan dari jamaah.

Sedangkan program ketiga adalah program dimana masjid harus mampu berperan menjadikan dirinya untuk menyejahterakan masyarakat di lingkungannya. Gerakan ini mewujud dalam banyak kegiatan seperti dibukanya klinik untuk pemeriksaan gratis bagi masyarakat, memberikan pinjaman/pemberian modal bagi masyarakat yang betul-betul membutuhkan, pemberian 25 paket beras kepada masyarakat tidak mampu setiap setengah bulan sekali. 
Dari beberapa kegiatan yang telah dilakukan, telah ada titik cerah yang bisa diharapkan untuk menjadikan Majlis Taklim az-Zahra sebagai lembaga amil zakat. Ada dua indikator yang bisa dicatat di sini. Pertama, komitmen dari anggota untuk menyalurkan zakatnya dengan penghitungan 2,5\% dari hasilnya setiap bulan untuk diserahkan kepada Majlis Taklim az-Zahra yang pada gilirannya dipergunakan untuk kepentingan social lebih luas untuk didistribusikan kepada yang berhak. Kedua, komitmen untuk melakukan gerakan mengumpulkan uang kecil setiap seminggu sekali ketika melaksanakan kegiatan pengajian di Majlis Taklim az-Zahra untuk selanjutnya dipergunakan untuk kepentingan yang lebih luas.

Hanya saja memang harus diakui ada beberapa kendala yang cukup serius dalam upaya untuk menjadikan Majlis Taklim az-Zahra sebagai lembaga amil zakat. Kendala ini lebih banyak disebabkan oleh Karakteristik yang lebih banyak berhubungan dengan cara berpikir, bukan pada ketrampilan, sehingga membutuhkan waktu yang relative lama. Kendala lain adalah kegiatan social memang tidak mudah untyuk dapat menarik minat masyarakat ikut bergabung menangani secara sungguh-sungguh.

\section{KESIMPULAN}

Indonesia adalah negara dengan penduduk beragama Islam terbanyak di dunia. Kondisi demikian, sangat potensial menjadikan Indonesia sebagai representasi wajah Islam di dunia. Islam dipersepsi sebagai sebuah agama yang santun dan sangat perhatian terhadap keadaaan masyarakat atau Islam dipersepsi sebagai agama yang tidak peduli dengan keadaan masyarakatnya, sangat ditentukan oleh bagaimana Indonesia memahaminya.

Untuk mewujudkan citra Islam Indonesia sebagai representasi Islam, khusunya dalam kaitannya dengan kesejahteraan sosil-ekonomi, perlu dibentuk lembaga amil zakat yang baik. Yang tentu bukan hanya semata menjadi tanggungjawab organisasi-organisasi besar, melainkan juga lembaga-lembaga kemasyarakatan yang sifatnya mengakar sampai ke tingkat yang paling rendah sekalipun sehingga dampaknya memang betul-betul bisa dirasakan oleh masyarakat.

Salah satunya adalah Majlis Taklim az-Zahra yang telah berusaha merintis keberadaannya bukan hanya sebatas sebagai sebuah kelompok pengajian yang berkutat dalam masalah ritualitas semata, tetapi juga melakukan berbagai aktivitas social. Lebih-lebih setelah diadakan pendampingan melalui berbagai kegiatan baik workshop, kajian-kajian, studi banding dan sebagainya. Terbukti telah mulai ada gerakan kecil yaitu mengumpulkan sedikit dana setiap seminggu 
sekali ketika ada pengajian. Satu tahap yang baik untuk menuju tahapan berikutnya, kendati masih dari idealitas yang diharapkan.datang.

\section{DAFTAR PUSTAKA}

Bakhri, Mokh. Syaiful, Sukses Koperasi Syariah di Sidogiri The Best Islamic Micro Finance, Cipta Pustaka Utama, 2015

Hafidhuddin, Didin, Zakat dalam Perekenomian Modern Jakarta, Gema Insani Pers.

Hidayatullah, Furqon, Pendidikan Karakter, Membangun Peradaban Bangsa.

Surakarta: Yuma Pustaka

Koentjaraningrat. Metode Penelitian Masyarakat. Jakarta: Gramedia, 1986.

Munawar-Rachman Budhy, Kontekstualisasi Doktrin Islam dalam Sejarah, Jakarta:

Paramadina, 1994

Quraish Shihab, Membumikan al-Quran, Bandung: Mizan, 1999.

Yusuf, Ahmad Muhammad, Ensklopedi Tematis Ayat al-Quran dan Hadits, Jakarta: Widya Cahaya, 2010.

Zuhaily, Wahbah, Zakat Kajian Berbagai Mą̧hab terj. Agus Effendi dan Bahruddin Fannany, Bandung Remaja Rosdakarya, 1997

Undang-undang Nomor 23 Tahun 2011 tentang Pengelolaan Zakat 
